\title{
Jacint Verdaguer, Andrejs Pumpurs and Petar Petrović Njegos: Three Moments in the Romantic National Epic of $19^{\text {th }}$-Century Europe
}

\section{MIGUEL ÁNGEL PÉREZ SÁNCHEZ}

\begin{abstract}
In the course of the $19^{\text {th }}$ century, from one extreme to another, literary manifestations of nationalism have shown up in several different genres, and meaningfully in the epic genre, which is perceived, according to the Western literary canon, with its beginning in the Greek epics of the Iliad and the Odyssey, as a primary expression of the cosmogonic myths of an ethnic group in search of the national identity.

This paper, through the analysis of the works of three major European poets, the Catalan Jacint Verdaguer, the Latvian Andrejs Pumpurs, and the Montenegrian Petar Petrovic Njegos, each one of them writing without knowing the other two, tries to state that despite the obvious social, historical, geographic and linguistic differences separating them (which are also the subject of research), there is one common spirit rooted in the Romantic Movement, connecting and providing them with similar motives and topics.
\end{abstract}

Keywords: Jacint Verdaguer, Andrejs Pumpurs, Petar Petrović Njegos, epic, Romanticism, nationalism

\author{
I want a hero: an uncommon want, \\ When every year and month sends forth a new one, \\ Till, after cloying the gazettes with cant, \\ The age discovers he is not the true one; \\ Of such as these I should not care to vaunt, \\ I'll therefore take our ancient friend Don Juan. \\ We all have seen him, in the pantomime, \\ Sent to the devil somewhat ere his time.
}

Byron's request for a hero, an uncommon one, at the beginning of his unfinished long poem Don Juan, is that of a generation of English Romantics who envisioned poetry not only as a vehicle for the search of identity and self-understanding (what is roughly speaking one of the main characteristics of this broad literary movement), but also as a vehicle that had to adopt the appearance of an epic, either to follow, in one way or another, its conventions, or to call them into question and reject them.

DOI: http://dx.doi.org/10.12697/IL.2015.20.1.4 
PÉREZ SÁNCHEZ

Wordsworth, Keats, Shelley, Byron, nowadays still well-known poets by the educated reader, all of them, at different moments of their literary careers, adopted the epic form, composing lengthy works in what Robert Southey, himself a Romantic poet, called "epomania" (Johns-Putra 2006: 117).

Milton, with his Paradise Lost, provided the mirror in which several generations of English poets, from William Blake, who made Milton the hero of one of his major poems, to the previously mentioned ones, looked at themselves, and did that for two reasons, both of significant importance to our purpose. Firstly, because Milton was seen as the highest literary exponent of a long protestant religious tradition and intellectual and spiritual independence, and his work, as the critic Harold Bloom states ${ }^{1}$, was interpreted as manifesting a sense of inner freedom and a rupture with the artistic conventions of the past. Not least so because Milton appeared to his eulogisers as the author of the most successful heroic epic of Christian subject after Dante, as well as the hero of his own life. He was seen as a prophet poet capable of defeating symbolically the old religion, leading the way to the eternal truth in Blake's vision and self-knowledge in the vision of Wordsworth or Byron:

The assumption that 'the heroic poet leads a heroic life' was, it would seem, at the bottom of Milton's achievement, as far as the leading Romantics were concerned. The Romantic epic is therefore an elaboration of what many Romantic-age poets saw as the aim of the Miltonic epic - to demonstrate the heroism of the poet within the context of the poem as well as to reveal that heroism in the completion of a majestically impressive poem. (Johns-Putra 2006: 115)

This conception of the epic form as a medium of poetic self-expression and philosophical, ontological research, is not, however, exportable beyond its own time and space, that is to say, beyond England in its transition to become, since the end of the eighteenth century and the first decades of the nineteenth century, the first industrialized country in Europe (it would be enough to remember that England is the subject of most of Marx's economic analysis in The Capital).

Lilian R. Furst, in her influential article "Romanticism in Historical Perspective", has demonstrated that the Romantic movement was not a homogeneous one, but had independent sources and different phases: "the spread

The best preparation for reading Romantic poetry always will be a close rereading of Book 1 of Spenser's The Faery Queen and of Milton's The Paradise Lost [...] Milton begins his poem with an invocation to the Muse, an epic device that he transforms into the summoning of the Holy Spirit of God, which "before all temples dost prefer / the upright heart and pure". (Bloom 1994: xviii) 
of Romanticism is characterized by curious time lags and unexpected spurts" (Furst 1968: 115). Starting in England a few decades before the turn of the century, although the first signs of change could be traced back to the mid-century, following in Germany with the rebellion of the Sturm und Drang against the restrictions of political, ideological and literary forms of the time, to develop later under the guise of the well differentiated groups of Jena and Heidelberg. Only in the second decade of the nineteenth century England returns to the focus of European Romanticism, and then only for ten years, after which finally Romanticism penetrates France. There the Revolution of 1789 created a public avid for rapid and truculent emotions and Napoleon's Empire, through censorship and a preference for classical "grandeur", had the paradoxical effect of paralyzing the necessity for a new kind of literature, which was seen, in its foreign manifestations, as associated with revolution and, therefore, stigmatized. From this moment on, in relation with its own political circumstances, a late wave of Romanticism spread across the rest of the European continent, in coexistence with more or less contemporary taste for realism that the rising capitalist society was starting to reveal.

These political circumstances, along with other ones of social and ethnographic kind, retarded the manifestation of Romantic signs as much as affected their appearance, for, broadly speaking, the main characteristic in this late wave is its manifestation as nationalism understood from an ideological and programmatic point of view, nationalism that in the case of the old nation states of England, France, Spain and Russia could adopt the aspect of patriotism or simple nostalgia for the past, but in the case of regions with a problematic identity took on the form of active defence of what Benedict Anderson has called "imagined communities"2.

Among the European communities with a problematic identity difference should be made between the ones with the tendency of unification of smaller parts (Germany and Italy) and those that were inclined to a separation from a bigger nation and which could be grouped in three areas: the Mediterranean area, the Central European and Balkan area and the Baltic area. Nevertheless, we should bear in mind that the processes which took place during the nineteenth and the twentieth centuries and in some cases have continued into our own days, resulted in the creation of differentiated nations which were not homogenous as far as the development of these processes completed the three phases

2 It is an imagined political community and imagined as both inherently limited and sovereign. It is imagined because the members of even the smallest nation will never know most of their fellow-members, meet them or even hear of them, yet in the minds of each lives the image of their communion (Anderson 1991: 15) 
PÉREZ SÁNCHEZ

of nationalism established by Hroch ${ }^{3}$ with a particular rhythm and not always going through every phase.

It was Germany, paradoxically a nation of addition, not of substraction, which had provided since the end of the eighteenth century the philosophical bases on which nationalism as an ideology was founded, and later, from the 1860s onwards, exported its Bismarckian - imperialist - prescription of "how to build a nation". Specifically, it was the German Idealism which, through the works of Herder, Fichte and Hegel, built up what the Spanish philosopher Gustavo Bueno has described in a prominent study (Bueno, 1996) as an obscurantist myth, that is, the invention of the idea of objective culture as a substitute or modern equivalent of the spiritual Kingdom of Grace. In short, the Christian soteriological conception of a fallen humanity that God raises by means of Grace, expressed through a set of external elements like revealed books or temples, the kind we can find already in Saint Augustine's writings, and the fragmentation of the Roman Empire into small medieval states coordinated by the central spiritual power of Rome, are both links of a chain that, after Luther's reform and the secularization of society at the end of the seventeenth century, led in Germany, itself eventually a "fallen nation"4 and, therefore, an enabling environment for these ideas, to the birth of Herder's philosophy in which the human being is "raised" to the condition of "cultural animal" in a process of historical objectification, for history in his thought becomes supra-individual and supra-subjective and culture the envelopment for the possibility of mankind (and every member of mankind) to raise its status above Nature. Finally, Fichte and Hegel further developed this idea, perceiving Culture as the secular equivalent to the Kingdom of Grace. The Nation was understood as something given, as the last stage in man's spiritual progress: der Volksgeist.

In conjunction with the exaltation of Culture as the cornerstone and one of the main constituents of the new Weltanschauung, started the movement of revaluation of the past, that is, the medieval past, in opposition to the universalist and to a good degree timeless, conception of history developed by Neoclassicism. It showed several manifestations of Volkspoesie, one of the first ones being in 1760 in the publication of Fragments of Ancient Poetry by the Scottish

3 He divided national movements into three phases A, B, and C; defined respectively as "the period of scholarly interest", "the period of patriotic agitation", and "the rise of a mass national movement".

4 "El pensamiento alemán, propio de una sociedad enferma, se dirigía principalmente hacia sí mismo, hacia su propia enfermedad y los medios para curarla.” "German thought, typical of a sick society, addressed mainly to himself, to his own illness and its cure”, translation mine.) (Goldmann 1974: 27-52, quoted in González 1999: 357) 
Three Moments in the Romantic National Epic of $19^{\text {th }}$-Century Europe

poet James Macpherson which quickly spread beyond the British shores and produced a real fashion for the recovering of what Friedrich Schlegel labelled as the expression of "the pure language, a language before the fall" (Steenbock 2002: 156).

The Brothers Grimm in Germany or Vuk Karadžić in Serbia are among the most eminent collectors of popular songs and tales in the earlier moments of the folklorist movement, although the limits of folklore and what Richard Dorson called fakelore (Dorson 1977: 4) - false folklore with the appearance of the real one - were not obvious at the time. Thus, Ossian, whose ballads his editor Macpherson claimed to have collected and translated form Gaelic into English were adapted and modified by the latter to suit his own taste.

All these factors contributed to the need of a narration with enough strength to support a myth like the nationalist one, which even if not perceived as a myth, could not be perceived as being supported by extrasomatic, objective facts, and that kind of powerful narration, according to the generic conventions of the eighteenth-century Europe still relevant in the next century, could only be carried forward by the epic genre. For since antiquity the epic genre had been, among the three defined by Aristotle - epic, lyric and dramatic -, the most prestigious one, and that even in spite of the upheavals the genre went through in its almost three thousand years of western history.

It is not the point of this article to discuss the nuances of a proper definition for this genre, see García-Berrio (2006), John's-Putra (2006) or Spang (1993) for further discussion. It will be enough to say that in western literature, the epic has had an evolution in content and form as dependent on its reception as on the poetics of the time, particularly when the poetics privileged some models of the past over others, favouring Homer and Virgil as the two models around which, since the Renaissance, the epic has gravitated.

The Iliad and the Odyssey by the fifth century B.C. had already enjoyed "a position of immense influence in Greek society, not simply as great poems but as a means of understanding the world" (Johns-Putra 2002: 35). They were a kind of encyclopaedia defining what the Hellenistic society was and what could be expected of its members in opposition to the Barbarian peoples, who could not be defined according to the same principles. Virgil's Aeneid, on the other hand, was born of the need felt in Rome to tell the "history of the world", that is, "the history of Rome" - understanding the "world" as cosmos, order against chaos. The epic's most interesting feature, leaving aside its written and not oral form, were the Homeric poems, with their nationalism, a nationalism not understood in terms of the nineteenth century ideology, but like a defence of "latinitas", meaning tradition and a way of life in the Roman sense. As David Quint suggests: 
Aeneas is not allowed to transfer affective ties to a collective Roman future; he is asked to give up the ties that constitute individual personality and will. [...] The Aeneid thus redefines the epic hero, whose heroic virtue now consists in the sacrifice of his own independent will - a will independent from his national mission. (Quint 1993: 83)

Both models of the epic, as indicated above, fared differently after antiquity. The Aeneid was revered in the Renaissance, although, on the one hand, it suffered due to the romances that changed its face (for example Ariosto's digressive Orlando Furioso) and, on the other hand, it was affected by Christian morality, turning the hero into somebody not in search of fame or defending his honour but aspiring to be merciful and pious. This Christianization of the pagan models led to their interpretation by means of allegory and its extensive use in the narration. ${ }^{5}$ The Iliad was influential in the Romantic period mostly because of its formal liberty of language, style and construction represented by poems of oral composition, and hence understood as Volkspoesie.

National Romanticism, for its own propagandist purposes, used the nationalist thought contained in the Aeneid, filtered through the Christian doctrine and manipulated by the philosophical Idealism as much as the formal liberty of the Homeric poems that referred to the breaking of rules of the Neoclassical period. And that is a critical difference that should always be borne in mind when considering the poetics of English, French, Spanish or Russian Romantics, and that of Romantics of "nations" in a real or imaginary process of being built - depending on which of the Hroch phases this process could be placed in.

Of the three main areas into which we divided the nineteenth century Europe with its nationalist tendencies, we would like to highlight three epic poems in order to contextualise them both in their (poly)system and in the framework of the larger polysystem of European literature to which they belong, despite the fact that the Western Canon (Bloom 1994) has kept them, at best, in a static canonicity (Even-Zohar 1990: 19), and more frequently, in simple ignorance. This we will do within the framework of mythocriticism and mythoanalysis, as defined by Gilbert Durand (Durand, 1960, 1979), the former being the study of texts through their symbols and the recurrent structures they form - mythemes; the latter being the study of myths defining a cultural period, which links mythoanalysis to comparative literature.

The Balkan area was characterised in the nineteenth century by its continuing efforts to escape the historic domination of the Ottoman Empire and the neighbouring emergent major power of the Austro-Hungarian Empire. In the

5 Spenser's The Faery Queen, Milton's Paradise Lost, Voltaire's La Henriade... 
Middle Ages Serbia and Croatia had been independent kingdoms but since the defeat of the Serbian troops by the invading army of the Ottoman Empire in the battle of the Kosovo Field in 1389, and the defeat of Croatian troops in the Battle of the Krbava (1493) Field and the Battle of Mohács (1526), after which the Croatian Parliament chose the Habsburgs as the new rulers of the country, they had lost their independence. This continuing state of violence due to blurred boundaries and a warlike population contributed through centuries to the creation of a big body of oral epic poetry similar in composition to ancient poetry, as Alfred Lord and Milman Parry have demonstrated (Lord, 1960).

Vuk Karadžić (1787-1864), the reformer of the Serbian language and orthography, gained a well-deserved fame throughout Europe as a collector of folkloric poetry (ballads, epic songs, lyrics). Admired and read from England to Russia, his influence can be traced in Goethe, the Grimm brothers, Lamartine, Pushkin, Runeberg (the composer of the second important national epic after the Kalevala in Finland) or lately, in the works of the Latvian folklore collector Krišjānis Barons.

This influence is noticeable in the figure of his compatriot (this term understood in the ethnic sense), Petar Petrović Njegos (1813-1851), Prince and Bishop (Vladika) of Montenegro and author of one of the most significant national epics of the century: Gorski Vijenac (The Mountain Wreath), published in 1847. Himself a collector of oral poetry like Karadžić (they were friends), Njegos, not a scholar but a ruler of one of the wildest, illiterate and bellicose regions of the South of Europe at the time, and for that same reason, extremely rich in poetry, was also Romantic through the teachings of his master, the Serbian poet and philosopher Sima Milutinović (Javarek 1952: 516) who was deeply involved in the fight for the liberation of the Balkan peoples from Turkish oppression.

Gorski Vijenac is an epic poem of 2819 verses that adopts the form of a tragedy not thought performable due to the huge number of its characters and the vagueness of time and space in which its minimal action is developed. The plot is based on the legendary event of the killing of Muslim converts by their Orthodox compatriots which supposedly happened at the end of the seventeenth century, and tells the reader about the doubts which beset the Bishop (Vladika) Danilo about the legitimacy of this procedure and his efforts to give it a better solution by means of a dialogue, a solution that in the end proves to be impossible. Although considered in Njegos' lifetime an authentic event, researchers like Antoine Sidoti have demonstrated that the massacre never happened as told (Sidoti in Njegos 2010: 34). ${ }^{6}$

6 “Mais de toute façon il n'est s'agit là que d'une tradition récente, qui ne paraît pas remonter en deçà des deux premières décennis du XIXe siècle... On trrouvait des 
The direct sources of the poem can be found in an epic song published in 1829 with the title Srpski Badnji Veče (The Serbian Christmas Eve) and by Sima Milutinović in 1837 with the title Sve-Oslobod (Totally Free) that later Njegos would add to his own collection of popular ballads Ogledalo srpsko (Serbian Mirror).

In the Mediterranean area the national consciousness woke up on those territories which, in the creation of the supra-national identities of France and Spain during the late Middle Ages, had been politically swallowed up and their languages and literature, despite having showed some splendour, had been pushed aside by their own users to access the benefits of a more universal and powerful culture. In Spain, the Galician and Catalonian movements of the Renaissance (Rexurdimento and Renaixença respectively), and in France the Occitan Félibrige movement, did not go beyond the phase of scholarly interest, although in the Catalonian case a real period of "patriotic agitation" took place at the turn of the nineteenth century and the first decades of the twentieth century. The main features of these movements were the scholarly and bourgeois origins of their propagandists, conservative in ideology. It was accompanied by the revival of public manifestations of medieval literary and courtly institutions - Jocs Florals in Catalonia or Courts d'amour in Provence - and a great concern for the standardisation of the language.

Jacint Verdaguer (1845-1902), priest and poet laureate of the Renaissance Catalan movement, preceded by a dull tradition of epic poetry datable approximately to the eighteenth century ${ }^{7}$, and under the influence of the Renaissance Catalan program and scholars like Milà i Fontanals or Bonaventura Carles Aribau, who had argued the need for renovating the epic tradition (Jorba 1986:

islamisés et des orthodoxes au sein d'une même famille et, comme pour les Moténégrins les liens du sang prévalaient sur les différences religieuses, l'idée d'un massacre général des musulmans par les chrétiens paraît peu crédible." "But anyway it is only a recent tradition, which does not seem to be current before the first two decades of the nineteenth century ... We could find Islamized and Orthodox people in the same family and, as for Moténégrins blood ties prevailed over religious differences, the idea of a general massacre of Muslims by Christians seems implausible”, translation mine.)

7 For instance, in reference to one of its exponents, Manuel Jorba writes: "El poema épic, doncs, existia d'abans de l'aparició d'un programa pròpiament renaixentista, i en el cas de Puigblanch, explicitament relacionat amb la finalitat (patrioètica malgrat les aspectes negatius que encobreix) de ser testimoni i testament de la llengua catalana." ("The epic, therefore, existed before the emergence of a truly Renaissance program, and in the case of Puigblanch was explicitly related to the purpose (patriotic despite the negative aspects that it conceals) to be witness and testament of the Catalan language", translation mine.) (Jorba 1986: 18) 
13-14), published in 1886 Canigó, the epic poem widely awaited by the Catalan intelligentsia and immediately received as the national epic of the nation in which its origins and destiny had successfully been articulated in a poetic way.

The subject of Canigó, divided into twelve songs, is simple. In the epoch of the Christian Reconquest against the Muslim occupation of the Iberian Peninsula, Gentil, the son of Count Tallaferro, disobeying his father's and uncle's orders, abandons his military obligations to pursue the love of Flordeneu, the queen of faeries, who inhabits the Canigó Mountain in the Pyrenees and at whose side he learns their history and legends till his uncle, Count Guifré, finds him and blaming him for the last defeat of the Christian army at the hands of the moors, kills him, after which he repents and in order to atone for his sins, he founds Sant Martí de Cuixà, later becoming Sant Martí de Ripoll, the mythical cradle of the Catalan nation.

The direct sources of the poem are of two types: folkloric poetry and legends about faeries, most of which Verdaguer himself could collect from local peasants or the literary tradition, and the Romantic historiography on the origins and continuity of Catalonia (Torrents 1987: 55).

During the nineteenth century, in the Baltic area Romanticism was introduced in different stages and unevenly. The regions under Russian influence (Lithuania, Latvia, Estonia) suffered a scarce social evolution with a small number of cities and a high percentage of peasants still living under the feudal regime. Several policies of Russification started to be promoted in the middle of the century, especially in Lithuania after the unsuccessful uprisings in 1831 and 1863 with the ban of the Lithuanian press and the cultural and educational closure of institutions. On the other hand, several measures for the emancipation of serfs were adopted at the beginning of the century - in 1816 in the province of Estonia and in 1819 in the province of Livonia - although they fully succeeded only in the 1860s (Plakans 1995: 100). This socio-political situation led to the Baltic area being one of the last in Europe to receive the Romantic Movement, and did it in the form of National Romanticism.

The publication of the Kalevala in 1849 by the doctor and scholar Elias Lönnrot after two decades of field work collecting folk poetry, especially from Finnish Karelia, was regarded by the Finnish intelligentsia as a cornerstone of the awakening movement, Kalevala as an authentic oral epic, and Lönnrot as an oral poet, a kind of Homer. ${ }^{8}$ After the success of the Kalevala, the first version of the Estonian epic poem Kalevipoeg (Kalev's Son) by Friedrich Reinhold Kreutzwald was published in 1857-1861 (seven issues with German translations), and the complete public version in 1862 in Kuopio (Finland) due to censorship reasons,

8 Against this persistent vision (Dundes 1985) 
PÉREZ SÁNCHEZ

while in Latvia Andrejs Pumpurs published his Lāčplēsis (The Bear Slayer) in 1888 .

It took Pumpurs (1841-1902) almost twenty years to finish his epic Lāčplēsis, succeeding in his reception among the Latvian public where previous attempts between the 1860s and 70s of creating a national epic had failed (Lāms 2007: 130). The subject of the poem is the fight of the mythical hero Lāčplēsis who defeats the German crusaders who in the thirteenth century invaded Latvian territories and imposed their presence for the next seven hundred years. Lāčplēsis, in spite of some victories over the enemy, finally is unable to complete the divine mission which the Baltic gods had imposed on him and disappears into the waters of the Daugava to return in the future when the day of liberation arrives for the Latvian people.

The direct sources of the poem can be found in popular motives of Latvian folklore, some of them already present in the works of other writers of the time (J. Alunāns, Atis Kronvalds, Auseklis); the Livonian Chronicle of Henry, a historic document in Latin describing the Northern Crusades carried out in Livonia (roughly corresponding to today's mainland Estonia and northern Latvia) and the surrounding areas from 1180 to 1227; Frīdrihs Mālbergis' epic poem Staburags un Liesma (Staburags and Liesma) which dwells upon the ancient eastern origins of the Latvian people (according to the nineteenth century ethnographers' beliefs) and the epic tradition of other regions (Rudzitis, in Pumpurs 1988: 59-60).

It would not be misleading, in light of data and from an operational point of view (for the genetic perspective here could prove to be fruitless) to consider the Kalevipoeg and Lāčplessis ${ }^{9}$ heirs of the Kalevala, and all three, along with other European national epics like the above-mentioned Canigó and Gorski Vijenac, on the one hand, heirs of Ossian, the first European work of Volkspoesie where folklore and fakelore shake hands, and, on the other hand, of the Nibelungenlied, the medieval epic which the German society, since the discovery in 1755 in Hohenems of some old manuscripts, referred to as the great national epic of their own "imagined community". Steenbock (2006) has analysed in great detail the difficult history of its reception.

The Romantic national epic is part of a big ideological system which, for its expression, uses a particular grammar, that is, a specific poetics. From the comparative study of Läčplēsis, Canigó and Gorski Vijenac some of its more characteristic features emerge. We have hitherto explored their common external

9 Even Pumpurs recognizes his debt to the Nibelungenlied in the prologue to his poem where he quotes the work of Wilhem Jordan, a German scholar who adapted and tried to popularize the medieval poem among the general public. (Rudzitis 1988: 141) 
history and the spiritual and cultural atmosphere in which they were born. Now we will try to briefly outline some of their inherent common traits.

Formally speaking, these three epic poems exhibit metric patterns associated with the traditional structure of the popular poetry of their own traditions. In the case of Gorski Vijenac that is very clear, for Njegos uses the traditional decasyllabic rhythmic pattern of epic Serbian poetry. For their part, lacking the tradition of oral epic poetry, Läčplessis' and Canigó's rhythmic structures are polymetric, a successful blend of traditional and learned rhythmic patterns, the first ones reserved for the lyric moments, the second ones used in the narration.

Far more interestingly, in terms of content, leaving aside the obvious differences in their plots, the two elements come together on the narratological level. The hero represents what Northrop Frye has called "archetypes" (Frye 1957, 1982); on the mythopoetic level, the mythemes link with the figure of the hero.

Lāčplēsis, Gentil and Bishop Danilo are quite different heroes. Actually, only Lāčplēsis acts as the real one, being a demigod born of a man and a bear and capable of superhuman actions. Like Aeneas, he has also been chosen by the gods and is fully dedicated to his special cause (Lāms 2007: 132-133). By contrast, Gentil appears an antihero, someone who evades fighting to pursue beauty and love; Bishop Danilo is like a man of reflection, tormented by doubts. Nevertheless, the differences are superficial, for they are used as "archetypes" of Jesus Christ (Frye 1982), vehicles of messianism and redemption for the "fallen nation", understood in the symbolic sense of the "ecclesia" or assembly of all the believers.

After the crucifixion of Jesus Christ, and we should not lose sight of the violence implicit in this act, his resurrection means for the believer the promise of salvation when the "Lamb of God" comes back at the end of the times to establish the Kingdom of God on Earth. In the same way, Lāčplēsis is sacrificed for the gods, who chose him as their champion to fight against the invader knowing that there was no more hope than "Christian" hope and this in the text supposedly anti-Christian and pro-Pagan. Thus, when the old Vaidelots brings the small Lāčplēsis to the King of Lielvārde for him to take care of him, he foretells: “... nolemts no diviem / Par tautas varoni vēlāki palikt [...] Dievi gan karos, dievi gan dzīvos, / Bet mūsu tautieši brīvību zaudēs, / Un mūsu slavenie varoṇi kritīs." ${ }^{10}$, two assumptions contradicting each other. Indeed, Lāčplēsis will die physically fighting against the Black Knight, but not spiritually, as some day he will finally defeat his enemy and return from the Daugava waters where both

10 "... chosen by the gods / to be the future hero of the people [...] The gods will fight or we'll live / but our countrymen their freedom will lose / and our famous heroes will fall", translation mine. 
PÉREZ SÁNCHEZ

of them fell: " Un ar reizi nāks tas brīdis, / Kad viņš savu naidnieku, / Vienu pašu lejā grūdis, / Noslīcinās atvarā, / Tad zels tautai jauni laiki, / Tad būs viña svabada." ${ }^{11}$

Also Gentil in Canigó is sacrified, killed by his own uncle, to give place to the foundation of the monastery of Sant Martí de Cuixà. Actually, as Ricard Torrents (Torrents 1987: 95), states: "Així, el poema, nascut com a "llegenda dels monestirs canigonencs del temps de la Reconquesta, esdevenia un poema allegòric: el naixement de Cataluny entre guerres d'alliberament contra moros $i$ fades i entre fundacions de monestirs és allegoria del seu renaixement, nou-cent anys després i sota la direcciò de l'Església"12

Bishop Danilo had been captured and tortured by the Turks and with that stigma in his past, he is not able to choose the way of revenge, that is, he is not able to accept his destiny like Jesus Christ was not able to accept his own. When the decision finally is taken, the cleansing of sins of the fallen people - the Montenegrian people who have allowed during centuries the occupation of the Turks and the conversion to Islam of their own brethren - can only be carried out by a bloodbath in which the enemy, the converts, become the "Lamb of God".

All three heroes are archetypes of biblical dimensions, and the price for the dream of an "imagined community" - this symbol recurs again and again - is, as we have seen, the sacrifice, the transfer of humanity and individual freedom in exchange of what Hegel would call "the absolute mind" (der absolute Geist) - the State. In this fundamental point lies the difference between a liberal Romanticism like the English one, in search of self-knowledge and artistic freedom, and the National Romanticism, obsessed with the other, the foreigner, the enemy.

The national epics of Romanticism have the soteriologic and demagogic nature of a dark myth, a myth embedded in a poetic narrative - the proper one derived from the old Homeric and Virgilian models - but not exempt from literary value, as the three epics studied here take a relevant part in their own literary canon. The main mythemes that give structure to such a dark myth and reveal it are the sacrificial and the resurrectional mythemes, as we just saw in connection with the figure of the hero, the mytheme of the Golden Age and the mytheme of

11 "And the time will come / that he his enemy / will plunge, / and will go out of the whirlpool. / Then a new golden time for the people / will arrive to live in freedom," translation mine.

12 "Thus, the poem, born like a "legend of the monasteries in Canigo Mountain at the times of the Reconquest", became an allegorical poem: the birth of Catalonia among liberation wars against the Moors and fairies, foundations and monasteries is the allegory of its own rebirth, nine hundred years later, under the leadership of the Church," translation mine. 
the escape from the historic time and the return to a non-linear, cyclical time but we will treat both of them under a unique name, for they are convergent.

In $L \bar{a}$ čplèsis, the Golden Age mytheme is clear as all the narrative effort turns around the fight against the cultural or religious innovations that the German conquerors want to introduce in the Baltic lands, even if that innovation is the future capital of Latvia, the city of Riga, that in the fourth Canto is described repeatedly as "dark" and its construction is mourned with the words drawing a picture of slavery and humiliation: "Riga, cik tu izlējuse / Mūsu brāḷ asinis!"13

In Canigó, the Golden Age mytheme depends mostly on the time the narration is placed in - the Middle Ages and the Spanish Reconquest against the moors - and the meaning of the Catholic religion as the stabilising and unifying force of Catalan society, a conservative and traditionalist force against modernity, cosmopolitism and the end of secular traditions, the reason why in all these epics the popular element, with its folkloric dances and songs, is so important: the "sardana" dance in Canigó, the "kolo" dance in Gorski Vijenac, or the old tales that Lāčplēsis and Laimdota read and learn together.

The mytheme of the Golden Age in Gorski Vijenac is in some ways presented in a contradictory manner because we know that the intention of Njegos in his poetic work and in his political activity was to bring Montenegro into modernity, taking it out of the Dark Age in which its peasant society lived. However, in his epic, through the stories of mythic times told by different characters and the mockery that the Voivoda Drashko makes of Venice and the Venetians after travelling there, it looks like he is supporting the traditional values of the Montenegrian society. So, for example, Drashko pictures the dungeons of Venice as the metaphor of the end of the corrupt world: "И чујте ме што вам Аанас кажем: / познао сам на оне тавнице / Аа су божју грАно преступими, / и Аа ће им царство погинути / и боьима у руке уьести." ${ }^{14}$

New mythemes could emerge if we expand the analysis to other national epics of Romanticism. Nonetheless, the main ones are the ones we have just explored. Through their analysis, together with the study of the narrative and structural form of the epics from which they come from, not a movement, but an ideology, a purpose and a machinery arise. The ideology, either liberal or conservative, is nationalism. Its vehicle and the machinery involved were not new ones, as the use of the epic as a way to advertise political and imperialist ideas comes from Virgil's Aeneid. These ideological and literary works have been

13 "Riga, how much blood has you shed from our brothers!", translation mine.

${ }_{14}$ "These dungeons drear have taught to me, / That such men must have greatly sinn'd. / And therefore shall their Kingdom fall, / - Fall into hands not so defil'd!" (Njegos, 1930) 
spreading through Europe and America for almost a century. The intelligentsia of every newborn or potential nation tried to give its people a literary mirror to look at themselves, at their past and their future, even if that was in the form of the most recent genre: the novel. These achievements, whatever their literary value is, still persist as the modern educational system flourishes, and it should be the goal of any non-nationalist critic to reveal their origins, development and mythic structure.

\author{
Miguel Ángel Pérez Sánchez \\ mperezs10@gmail.com \\ Visvalža iela 4a \\ LV-1050 Riga \\ LATVIJA
}

Bibliography

Anderson, B. 1991. Imagined Communities: Reflections on the Origin and Spread of Nationalism. London: Verso.

Bloom, H. 1994. The Western Canon. New York: Riverhead Trade.

Bueno, G. 1996. El mito de la cultura. Barcelona: Prensa Ibérica.

Dorson, R. 1977. American Folklore. Chicago: University of Chicago Press.

Dundes, A. 1985. Nationalistic Inferiority Complexes and the Fabrication of Fakelore: A Reconsideration of Ossian, the Kinder- und Hausmärchen, the Kalevala, and Paul Bunyan. - Journal of Folklore Research, Vol. 22, No. 1, 5-18.

Durand, G. 1960. Les structures anthropologiques de l'imaginaire. Paris: Dunod.

Durand, G. 1979. Figures mythiques et visages de l'œuvre. De la mythocritique à la mythanalyse. Paris: Berg International.

Even-Zohar, I. 1990. Polysystem Studies. - Poetics Today. Durham: Duke University Press.

Frye, N. 1982. The Great Code the Bible and Literature. New York: Harvest Books.

Frye, N. 1982. 2000. The Anatomy of Criticism. Princeton: Princeton University Press.

Furst, L. R. 1968. Romanticism in Historical Perspective. - Comparative Literature Studies, Vol. 5, No. 2, 115-143.

García-Berrio, A. 2006. Los géneros literarios: sistema e historia. Madrid: Cátedra.

González, L. A. 1999. Los fundamentos de la filosofía idealista alemana: Kant, Fichte, Schelling. - Realidad: Revista de ciencias sociales y humanidades, No. 69, 357-383.

Javarek, V. 1952. Petar Petrovic Njegos (1813-51). - The Slavonic and East European Review, Vol. 30, No. 75.

Johns-Putra, A. 2006. The History of the Epic. London: Palgrave Macmillan.

Jorba, M. 1986. Introducció a l'èpica catalana del segle XIX. - Anuari Verdaguer, 1, 11-33. 
Three Moments in the Romantic National Epic of $19^{\text {th }}$-Century Europe

Lāms, O. 2007. The Interaction of Power and Culture in Perception of the Latvian Epic Lāčplèsis. - J. Osmond, A. Cimdina, eds., Power and Culture: Identity, Ideology and Representation. Pisa: Pisa University Press, 127-137.

Lord, A. B. 1960. The Singer of Tales. Cambridge: Harvard University Press.

Njegos, P. P. 2010. La couronne de Montagne. Paris: Editions Non Lieu.

Plakans, A. 1995. The Latvians: A Short History. Stanford: Hoover Institution Press Publication.

Njegoš, P. II P. 1930. The mountain wreath. London: George Allen \& Unwin, Ltd. Available in: http://www.rastko.rs/knjizevnost/umetnicka/njegos/mountain_wreath. html

Pumpurs, A. 1988. Läčplēsis. Rīga: Zinātne.

Quint, D. 1993. Epic and Empire. New Jersey: Princeton University Press.

Spang, K. 1993. Géneros literarios. Madrid: Síntesis.

Steenbock, M. 2002. Mito, Historia y Literatura: El fenomeno de los Nibelungos. México, D.F.: FcFyL UNAM.

Torrents, R. 1987. Contribució a l'estudi de la gènesi de “Canigó”, de Verdaguer. Anuari Verdaguer, 1, 71-98. 